Original Research Article

\title{
A pharmacological study on the effect of calendula officinalis extract on wound healing in animals
}

\author{
Ranjeet Kumar $^{1}$, Sarju R. Zilate ${ }^{1 *}$, Sushil $\operatorname{Varma}^{2}$, Sweety Kumari ${ }^{1}$
}

\begin{abstract}
${ }^{1}$ Department of Pharmacology, Raipur Institute of Medical Sciences (RIMS), Raipur, CG, India

${ }^{2}$ Department of Pharmacology, Mahatma Gandhi Institute of Medical Sciences (MGIMS), Sevagram, Wardha,

Maharashtra, India
\end{abstract}

Received: 22 April 2019

Reviewed: 26 April 2019

Accepted: 01 May 2019

\section{*Correspondence to:}

Dr. Sarju R. Zilate,

Email: drrahulkkg@gmail.com

Copyright: (C) the author(s), publisher and licensee Medip Academy. This is an openaccess article distributed under the terms of the Creative Commons Attribution NonCommercial License, which permits unrestricted noncommercial use, distribution, and reproduction in any medium, provided the original work is properly cited.

\begin{abstract}
Background: Calendula officinalis is one of those plants which have medicinal importance due to its flowers (HECO) has pharmacological activity the important pharmacological parameters have been less investigated properly and can be scientifically proved by reverse pharmacology. It was found of interest to evaluate these properties of extract of flowers of Calendula officinalis.

Methods: Study was conducted in Albino Wistar rats. For evaluating wound healing activity Excision wound model and Incision wound mode were used containing 4 groups each. The wound contraction was studied by tracing the raw wound area on graph paper. Scar area and time for complete epithelisation were measured. The percentage of wound contraction was recorded. The differences between experimental groups were compared by ANOVA followed by Students " $\mathrm{t}$ " unpaired test.

Results: In the excision wound healing model, $5 \%$ and $10 \%$ flowers showed a highly significant reduction in wound area as compared with control. In incision wound model, rats treated with $5 \%$ and $10 \%$ ointment of Calendula officinalis flowers extract showed highly significant increase in tensile strength as compared to control.

Conclusions: It was found that the Calendula extract enhanced the wound healing in both the models as seen by increased synthesis of connective tissue especially collagen. There was a significant increase in the granuloma tissue. In both the models wound contraction and increased tensile strength was found to be statistically significant.
\end{abstract}

Keywords: Calendula Officinalis, Excision wound Model, Incision Wound Model, HECO, Wound healing

\section{INTRODUCTION}

The primitive man observed and appreciated the great discovery of plants available to him. Herbs contains various natural substances that are capable of producing physiological and pharmacological effects on the body. Drugs made from herb are sometimes referred as "Herbalism" or "botanical medicine" for their therapeutic or medicinal values Drugs made from herbs have made their importance felt in the last few decades whose prevalence is continuously increasing in both developing and developed countries due to they are natural in origin and lesser side effects. ${ }^{1,2}$ Nearly $80 \%$ of the world's population use herbal medicine according to World Health Organization (WHO) for some aspect of primary health care. ${ }^{3}$ Medicinal plants have immense potential due to the databases collected through use of reverse pharmacology since ancient time. Hence, there has been great focus on 
plant research all over the world. There has been a surge in the use of herbal drugs for various diseases. ${ }^{4}$ Despite such intensive research on various herbal medicines, many species of plants are still left unexplored. Therefore, plants named Calendula officinalis is chosen for the present study. Calendula officinalis has been known since antiquity, as Pot marigold or English marigold an aromatic herb. The different parts of Calendula officinalis have been found useful in a variety of symptoms and disorders. Calendula officinalis is one of those plants which have medicinal importance due to its flowering part has pharmacological activity. The plant is rich in many pharmaceutical active ingredients like carotenoids, auroxanthin, flavoxanthin, flavonoids, glycosides, terpenoids esters, steroids and sterols, coumarins, amino acids. It is used as analgesic, antidiabetic, antiinflammatory, antiseptic, bactericide, in skin problems, and as antifungal agent. ${ }^{5-7}$ In the UK, the decoction of the flowers was used as a potent drink for the treatment of smallpox and measles, fresh juice as a remedy for jaundice, costiveness (constipation) and suppression of menstrual flow. ${ }^{8}$ In India, florets are used in ointments for treating herpes, ulcers, wounds, frostbite, skin damage, scars and blood purification while the leaves, in infusion, used for treating varicose veins externally. ${ }^{8}$ The important pharmacological parameters of Calendula officinalis have been less investigated properly and can be scientifically proved by reverse pharmacology. Therefore, it was found of interest to evaluate these properties of extract of flowers of Calendula officinalis scientifically in experimental models.

\section{METHODS}

The present study was conducted in experimental animals i.e. Albino Wistar rats. Animals were procured from Datta Meghe Institute of Medical Sciences, Sawangi (Meghe), Maharashtra after taking permission from Institutional animal ethical committee. The animals were caged in polyvinyl wire mesh cages in the central animal room of the institute approved by CPCSEA. They were maintained under standard laboratory condition (12-hour light and dark cycle and temperature of $220 \mathrm{C}+30 \mathrm{C})$, humidity $(60$ $\pm 10 \%$ ) with access to food and water ad libitum according to OECD guidelines, revised draft guidelines 425 and by the Committee for the Purpose of Control and Supervision of Experiments on Animals (CPCSEA), Ministry of Social Justice and Empowerment, Government of India9. The animals were allowed to adapt to the new surrounding by giving rest of one week before subjecting them to experimentation.

\section{Rats}

Healthy Wistar rats of either sex weighing between180250 grams (8 to12 weeks old) were used.

\section{Drugs and Chemicals}

Soframycin 30 gm (Aventis Pharma Limited, Goa), ointment, Ketamine hydrochloride (NEON Laboratories limited thane).

Equipment used in this study was Silk - [3-0] (Centenial Surgical Suture Limited Thane, Mumbai).

Ethical clearance was taken from Institutional Ethics Committee and Institutional Animal Ethics Committee (IAEC) before commencement of the study.

\section{Collection of plant material}

Fresh flowers of Plant Calendula officinalis were collected from the nearby area of Wardha and authenticated by a local experienced botanist of Institute - JB College of Science, (Janki Devi Bajaj College of Science) Wardha, Maharashtra, India.

The flowers were shade-dried, powdered in an electric mixture and stored in an air tight container for study.

\section{Preparation of extract}

The hydro-alcoholic extracts were obtained by soxhlet extraction at $60^{\circ} \mathrm{C}$ using $70 \% \mathrm{v} / \mathrm{v}$ ethanol as a solvent. Extract obtained by this method was shed dried and yield was measured. Fresh solution was prepared by dissolving extract in distilled water before each experiment.

The yield of flowers extract by soxhlet extraction is $8 \mathrm{gm}$ from $40 \mathrm{gm}$ of powder.

\section{Preparation of drug formulation}

For oral administration fresh solution was prepared by dissolving the Calendula officinalis flowers extract in distilled water before each experiment. Whereas for topical application Calendula officinalis flowers extract was mixed with simple ointment as mention. ${ }^{9}$

\section{Preparation of ointment}

\section{Simple ointment (100gm IP)}

- $\quad$ Soft Paraffin - 85 gm

- Hard Paraffin - 10 gm

- Lanolin/wool fat- $5 \mathrm{gm}$

$5 \%$ (w/w) ointment:

Simple ointment- 95gm

CO flowers extract- $5 \mathrm{gm}$

10\% (w/w) ointment:

Simple ointment- $90 \mathrm{gm}$

CO flowers extract- $10 \mathrm{gm}$

\section{Method for evaluating wound healing activity}

\section{Excision wound model $^{10,11}$}

The albino Wistar rats of either sex were divided into 4 groups, 6 animals in each group (total 24 animals)

- Group 1-Control-simple ointment locally once daily 
- Group 2- HECO extract (5\% ointment) locally once daily

- Group 3- HECO extract (10\% ointment) locally once daily

- Group 4- Standard drug Soframycin ointment locally once daily

The animals were anesthetized by using ketamine hydrochloride $(60 \mathrm{mg} / \mathrm{kg}$ i.p $) .{ }^{10}$ An impression was made on the dorsal thoracic region $1 \mathrm{~cm}$ away from vertebral column and $5 \mathrm{~cm}$ away from ear on the anaesthetized rat. The particular skin area was shaved one day prior to the experiment. The skin of impressed area was excised to the full thickness to obtain a wound area of about $500 \mathrm{~mm} .^{2}$ Haemostasis was achieved by blotting the wound with cotton swab soaked in normal saline. The wound contraction was studied by tracing the raw wound area on the subsequent day $1,4,8,12,16,18$ and 21 on graph paper. Scar area and time for complete epithelisation were also measured. The percentage of wound contraction was recorded.

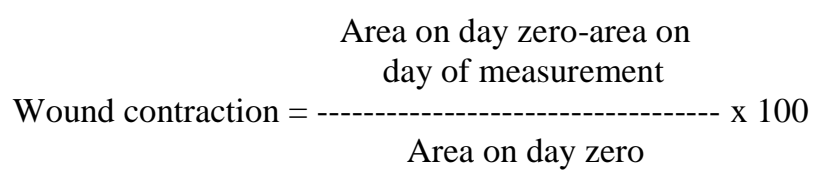

\section{Incision wound model ${ }^{12-14}$}

The albino Wistar rats of either sex were divided into 4 groups, 6 animals in each group (total 24 animals)

- Group 1-Control- Simple ointment locally once daily

- Group 2- HECO extract (5\% ointment) locally once daily

- Group 3- HECO extract (10\% ointment) locally once daily

- Group 4- Standard drug Soframycin ointment locally once daily

The animals were anesthetized by using ketamine hydrochloride $\left(60 \mathrm{mg} / \mathrm{kg}\right.$ i.p.). ${ }^{10}$ Para vertebral straight incision of $6 \mathrm{~cm}$ length was made through the entire thickness of the skin, on either side of the vertebral column with the help of a sharp scalpel. After complete haemostasis, the wound was closed by means of interrupted sutures placed at equidistance points about 1 $\mathrm{cm}$ apart. Animals were treated once a day with drugs (HECO ointment and Soframycin) from 0 day to 9th postwounding day. The wound breaking strength was estimated on 10th day by continuous, constant water flow technique as describe by Lee KH. ${ }^{13}$ The breaking strength was expressed as minimum weight of water necessary to bring about gaping of area.

\section{Statistical analysis}

All the results were expressed as Mean \pm Standard Deviation (SD). The differences between experimental groups were compared by one-way Analysis of Variance (ANOVA) followed by Students " $t$ " unpaired test. The results were considered statistically significant when $* \mathrm{p}$ $<0.05, \quad * * p<0.01$-very significant, $* * * p<0.001$-Highly significant as compare to control.

\section{RESULTS}

The wound contraction was studied by tracing the raw wound area on the subsequent day 1, 4, 8, 12, 16, 18 and 21 on graph paper. Scar area and time for complete epithelization were also measured.

In the excision wound healing model, 5\% and 10\% HECO flowers showed a highly significant reduction in wound area from Day $4(\mathrm{p}<0.001)$ as compared with control. Whereas standard, Soframycin showed a highly significant reduction in wound area from Day $4(\mathrm{p}<0.001)$ in comparison with control (Table 1).

Wound healing activity of hydroalcoholic extract of Calendula officinalis flowers by Excision wound model on rats showing period (in days) of epithelialization can be seen in Figure 1 and details also can be seen in Table 1 under the section of period of Epithelialization.

Rate of epithelialization was recorded in different groups and we observed that the rate of epithelialization for $10 \%$ HECO is almost comparable to standard i.e Soframcin Ointment. (Figure 1).

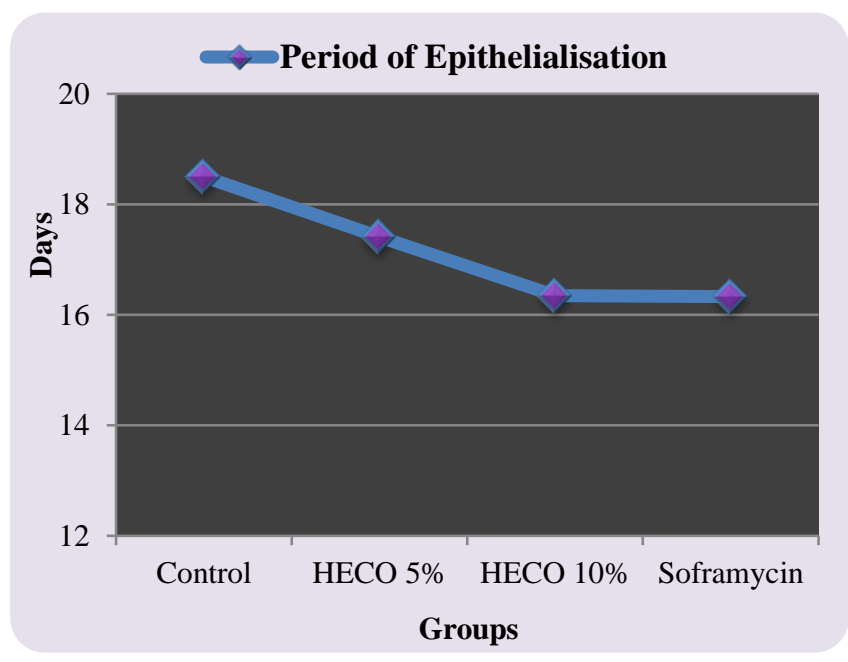

Figure 1: Wound healing activity of hydroalcoholic extract of Calendula officinalis flowers by excision wound model on rats showing period (in days) of epithelialization in different group.

In incision wound model, rats treated with $5 \%$ and $10 \%$ ointment of Calendula officinalis flowers extract showed highly significant $(p<0.001)$ increase in tensile strength as compared to control. Whereas standard Soframycin also shows highly significant $(\mathrm{p}<0.001)$ increase in tensile strength as compared to control and tensile strength for $10 \%$ HECO is almost comparable to standard, Soframycin 
ointment. (Table 2). The wound breaking strength was estimated on 10th day by continuous, constant water flow technique. The breaking strength was expressed as minimum weight of water necessary to bring about gaping of area.

Table 1: Wound healing activity of hydroalcoholic extract of Calendula officinalis flowers by Excision wound model on rats.

\begin{tabular}{|c|c|c|c|c|c|c|c|}
\hline \multirow{2}{*}{ Group } & \multicolumn{6}{|c|}{ Post wounding days wound area(mm3) Mean \pm SEM(Percentage of wound contraction) } & \multirow{2}{*}{$\begin{array}{l}\text { Period of } \\
\text { epithelialisation }\end{array}$} \\
\hline & Day 1 & Day 4 & Day 8 & Day 12 & Day 16 & Day 18 & \\
\hline $\begin{array}{l}\text { Control } \\
\text { (Simple } \\
\text { ointment) }\end{array}$ & $497.16 \pm 2.22$ & $\begin{array}{l}387 \pm 2.82 \\
(22.16)\end{array}$ & $\begin{array}{l}241.33 \pm 4.84 \\
(51.46)\end{array}$ & $\begin{array}{l}120 \pm 2.82 \\
(75.86)\end{array}$ & $\begin{array}{l}49.33 \pm 2.16 \\
(90.08)\end{array}$ & $\begin{array}{l}23.83 \pm 1.16 \\
(95.21)\end{array}$ & $18.50 \pm 0.44$ \\
\hline $5 \% \mathrm{HECO}$ & $496.33 \pm 2.94$ & $\begin{array}{l}371 \pm 3.74 * * * \\
(25.25)\end{array}$ & $\begin{array}{l}212.50 \pm 4.96 * * * \\
(57.19)\end{array}$ & $\begin{array}{l}99 \pm 3.74 * * * \\
(80.05)\end{array}$ & $\begin{array}{l}26.33 \pm 2.33 * * * \\
(94.70)\end{array}$ & $\begin{array}{l}7.50 \pm 1.04 * * * \\
(98.49)\end{array}$ & $17.41 \pm 0.38 * * *$ \\
\hline $10 \% \mathrm{HECO}$ & $495 \pm 4.14$ & $\begin{array}{l}347 \pm 3.74 * * * \\
(29.90)\end{array}$ & $\begin{array}{l}177.50 \pm 3.08 * * * \\
(64.14)\end{array}$ & $\begin{array}{l}58.33 \pm 4.96 * * * \\
(88.22)\end{array}$ & $\begin{array}{l}6 \pm 1.41 * * * \\
(98.79)\end{array}$ & $\begin{array}{l}0 \pm 0 \\
(100)^{* * *}\end{array}$ & $16.35 \pm 0.37 * * *$ \\
\hline Soframycin & $495.33 \pm 3.93$ & $\begin{array}{l}325 \pm 3.74 * * * \\
(34.39)\end{array}$ & $\begin{array}{l}173 \pm 3.74 * * * \\
(65.07)\end{array}$ & $\begin{array}{l}63.66 \pm 4.63 * * * \\
(87.15)\end{array}$ & $\begin{array}{l}7.16 \pm 1.47 * * * \\
(98.55)\end{array}$ & $\begin{array}{l}0 \pm 0 * * * \\
(100)\end{array}$ & $16.33 \pm 0.21 * * *$ \\
\hline
\end{tabular}

Note - Number of animals $n=6$. One-way ANOVA followed by Student's " $t$ " unpaired test. Results are expressed in Mean \pm SEM: *p $<0.05$ significant, $* * p<0.01$ - very significant and $* * * p<0.001$ - highly significant as compared to control. HECO-Hydroalcoholic extract of Calendula officinalis flowers.

Table 2: Wound healing activity of hydro alcoholic extract of Calendula officinalis by incision method on rats.

\begin{tabular}{|lll|}
\hline \multicolumn{1}{|c|}{ Group } & Dose $\mathbf{~ m g / k g}$ & Tensile Strength (gm) \\
\hline Control & Simple Ointment & $332.66 \pm 3.26$ \\
\hline HECO & $5 \%$ Ointment & $386 \pm 7.58 * * *$ \\
\hline HECO & $10 \%$ Ointment & $474.33 \pm 3.66 * * *$ \\
\hline Standard & Soframycin & $481.50 \pm 2.50 * * *$ \\
\hline
\end{tabular}

Note: Number of animals $\mathrm{n}=6$. One-way ANOVA followed by Student's “t” unpaired test. Results are expressed in Mean \pm SEM: *p $<0.05$ significant, $* * \mathrm{p}<0.01$ - very significant and $* * * \mathrm{p}<0.001$ - highly significant as compared to control. HECO-Hydroalcoholic extract of Calendula officinalis flowers

\section{DISCUSSION}

Wound healing is a complex, natural and dynamic process of restoring dermal and cellular structures as closely as possible to its normal and original state. ${ }^{15}$ In the event of any injury, a set of overlapping events takes place to repair the damage. ${ }^{16}$ Wound healing has been discussed into phases which include the inflammatory, proliferative and the maturational or remodelling phases. ${ }^{17}$ The process of wound healing depends upon the type and extent of damage occurred and also it depends on the general health of the host and its ability to repair. After the injury, haemostatic process takes place which prevent further blood loss and provide the initiation for other phases namely inflammation, proliferation and remodelling. ${ }^{18}$ In the inflammatory phase of healing, neutrophils and macrophages are attracted into the injured tissue and they locate and phagocytize, kill and digest microorganisms and eliminate wound debris. ${ }^{19}$ Inflammatory phase is followed by angiogenesis, collagen deposition, granulation tissue formation and epithelialization in proliferative phase. ${ }^{20}$

In the inflammation phase of healing, neutrophils and macrophages eliminate wound debris through their characteristic 'respiratory burst' activity and phagocytosis. At higher concentrations, radical oxygen species (ROS) can cause damage to cellular membranes, DNA, proteins and lipids and thus impede the healing process. ${ }^{21}$ Thus a compound or a plant extract which possess antioxidant potentials and antimicrobial activity can produce a potential therapeutic agent for wound healing.

Wound contracture begins 4 to 5 days after injury. It helps to close the wound gap between dermal edges and reducing the wound surface area. It is due to the action of myofibroblasts. Granulation tissue of the wound is a tissue formed in the inflammatory phase of wound healing. It is composed of blood vessels, macrophages and fibroblast with a loose connective tissue matrix. The cells contract the wound and produce large amount of ECM components. Collagen is a major constituent in remodelling phase. It composed of amino acid (hydroxyproline) which gives strength and support. Breakdown of collagen liberates free hydroxyproline and its peptides; measurement of the hydroxyproline could be used as an index for collagen turnover. ${ }^{22}$ Collagen formation occurs at a rapid rate in the initial phases of wound healing followed by the breakdown of collagen by collagenases in the remodelling phase where 
the undergoing processes are the collagen cross linking and thus increases the tensile strength.

It was found that the Calendula extract enhanced the wound healing as seen by increased synthesis of connective tissue especially collagen. There was a significant increase in the hydroxyproline content of granuloma tissue, which is a marker of collagen synthesis. Hexosamine is the ground substratum for the collagen synthesis and is known to increase during the early stages of wound healing and decreased thereafter. There was a significant increase in the level of hexosamine in the drug treated groups on initial days which can be co-related as the efficiency of the drug to enhance the synthesis of connective tissue.

In the excision wound model, 5\% ointment and $10 \%$ ointment of HECO flowers extract showed highly significant reduction in wound area from Day 4 onwards ( $p$ $<0.001)$ as compare to control.

In the incision wound model, animals treated with 5\% ointment and $10 \%$ ointment of HECO flowers showed highly significant increase in tensile strength as compare to control ( $\mathrm{p}<0.001$ and $\mathrm{p}<0.001$, respectively).

It has role in wound healing processes. Flavonoids of the plant, Calendula officinalis may thus contribute an additive effect to the endogenous anti-oxidants and may inhibit the eicosanoid biosynthesis. Flavonoids and their derivatives are known to decrease lipid peroxidation by improving vascularity and also by slowing cell necrosis. It decreases the formation of the inflammatory metabolites and prevents further damage. Thus flavonoids by virtue of its free radical scavenging, antioxidant and anti-inflammatory properties helps in healing of wounds. ${ }^{23}$

The process of wound healing is promoted by several natural and plant products, which possess the active principles like flavonoids, triterpenes, alkaloids, tannins and other biomolecules. It has been reported that the flavonoids promote the wound healing property by producing artificial cross linkage. ${ }^{24}$ Flavonoids are also potent antioxidants. It has been found that carotenoids mainly, $\beta$-carotene can enhance the wound strength in animal model. ${ }^{25}$

\section{CONCLUSION}

Wound healing activity of HECO is seen in graded dose. $10 \%$ HECO has wound healing activity almost comparable to the standard, Soframycin. In HECO, flavonoids due to its anti-oxidant activities, helps in reducing inflammatory mediators, increase vascularity and decrease cell necrosis. The plant also has antibacterial activities which help in wound healing. The plant also contains triterpenoids which help in reducing the inflammatory process. Further studies can give more strong correlation and association of HECO with wound healing and can be utilize in Health care systems.

\section{ACKNOWLEDGEMENTS}

Authors would like to thank Professor and Head, Dept. of Pharmacology, MGIMS Medical College, Sevagram, Wardha for his always available guidance to them.

\section{Funding: No funding sources}

Conflict of interest: None declared

Ethical approval: The study was approved by the Institutional Animal Ethics Committee

\section{REFERENCES}

1. Kumar KLS, Mustapha MH, Rajbhandari A, Ramakrishnan R. Phytochemical and Pharmacological Studies on Achillea Millefolium (L) Leaves. Res J Pharm Biol Chem Sci. 2011;2(1):24-30.

2. Mukherjee PK, Maiti K, Mukherjee K, Houghton PJ. Leads from Indian medicinal plants with hypoglycemic potentials. J Ethnopharmacol. 2006 Jun 15;106(1):1-28.

3. Waheed M, Deeba F, Syed R, Ali Y, Zeeyauddin K, Alshatwi A. Unani drug formulation for its analgesic, inflammatory and non-toxic effect. Int J Pharm Pharm Sci. 2011;3(4):66-72.

4. Craig WJ. Health-promoting properties of common herbs. Am J Clin Nutr. 1999 Sep 1;70(3):491S-499.

5. Bakó E, Deli J, Tóth G. HPLC study on the carotenoid composition of Calendula products. J Biochem Biophys Methods. 2002 Oct 1;53(1-3):241-50.

6. Dumenil G, Chemli R, Balansard C, Guiraud H, Lallemand M. [Evaluation of antibacterial properties of marigold flowers (Calendula officinalis L.) and mother homeopathic tinctures of C. officinalis L. and C. arvensis L. (author's transl)]. Ann Pharm Françaises. 1980 Jan;38(6):493-9.

7. Kasiram K, Sakharkar PR, Patil AT. Antifungal activity of Calendula officinalis. Indian J Pharm Sci. 2000;6:464.

8. Khare CP. Indian Medicinal Plants: An Illustrated Dictionary. Springer Science \& Business Media; 2008:900.

9. OECD guidelines for the testing of chemicals. Acute Oral Toxicity: Up - and - Down Procedure) [Internet] 1998 [Updated 1998 Sep 21; cited 2013 Oct 08]. Available at: http:// http://iccvam.niehs.nih.gov/SuppDocs/Fed Docs/OECD/OECDtg425.pdf.

10. Youth RA, Simmerman SJ, Newell R, King RA. Ketamine anesthesia for rats. Physiol Behav. 1973;10:633-6.

11. Morton JJ, Malone MH. Evaluation of vulneray activity by open wound procedure in rats. Arch. Int Pharmacodyn Ther. 1972 Mar;196(1):117-26.

12. Ehrich HP, Hunk TK. Effect of cortisone and anabolic steroids on tensile strength of healing wound. Ann Surg. 1969;170:203-6.

13. Lee KH. Studies on the mechanism action of salicylates. 3. Effect of vitamin A on wound healing 
retardation action of aspirin. J Pharm Sci. 1968 Jul;57(7):1238-40.

14. Somayaji SN, Jacob AP, Bairy KL. Effect of tolmetin and its copper complex on wound healing. Indian $\mathbf{J}$ Exp Biol. 1995 Mar;33(3):201-4.

15. Clark RAF. Cutaneous tissue repair. I. Basic biologic consideration. J. Am. Acad. Dermatol. 1985 Nov 1;13(5):701-25.

16. Lonac M, Parnham MJ, Plauchithiu M, Brune K. Oxaceprol. An atypical inhibitor of inflammation and joint damage. Pharmacol Res. 1996 Jun;33:367-73.

17. Iba Y, Shibata A, Kato M, Masukawa T. Possible involvement of mast cells in collagen remodeling in the late phase of cutaneous wound healing in mice. International Immunopharmacol. 2004 Dec 20;4(14):1873-80.

18. Schilling JA. Wound healing. Surg Clin North Am. 1976; 56:859-74.

19. Clark LA, Moon RE. Hyperbaric oxygen in the treatment of life-threatening soft-tissue infections. Respiratory Care Clinics of North America. 1999;5(2):203-19.

20. Midwood KS, Williams LV, Schwarzbauer JE. Tissue repair and the dynamics of the extracellular matrix. Int J Biochem Cell Biol. 2004;36(6):1031-7.
21. Loft S, Poulsen HE. Cancer risk and oxidative DNA damage in man. J Mol Med. 1996 Jun 1;74(6):297312.

22. Kumar R, Katoch SS, Sharma S. $\beta$ - Adrenoceptor agonist treatment reverses denervation atrophy with augmentation of collagen proliferation in denervated mice gastrocnemius muscle. Indian $\mathrm{J}$ Exp Biol. 2006;44:371-6.

23. Bent HH. The biochemistry and medical significance of flavonoids. Pharmacol Thera. 2002;96:80-112.

24. Kuppast IJ, Nayak PV. Wound healing activity of Cordia dichotoma Forst. f. fruits. Natural Product Radiance. 20065;99-102.

25. Gerber LE and Erdman JW. Effect of dietary retinyl acetate, $\beta$-carotene and retinoic acid on wound healing in rats. Journal of Nutrition. 1982 Aug 1;112(8):155564.

Cite this article as: Kumar R, Zilate SR, Varma S, Kumari S. A pharmacological study on the effect of calendula officinalis extract on wound healing in animals. Int J Basic Clin Pharmacol 2019;8:1209-14. 